\title{
Boron-loaded liquid scintillator
}

\author{
I.B.Nemchenok ${ }^{* * *}, N_{*}^{*}$ A.Gundorin ${ }^{*}$, I.I.Kamnev ${ }_{* * * *}^{* *}$, \\ E.A.Shevchik*,A.A.Shurenkova*,*** \\ *Joint Institute for Nuclear Research, 6 Joliot Curie St., Dubna, Russia \\ *: "Dubna" University, 19 Universitetskaya St., Dubna, Russia
}

Received November 30, 2013

\begin{abstract}
The high thermal neutron capture cross-section of ${ }^{10} \mathrm{~B}$ nucleus enables to use the boron-loaded organic scintillators as a basis of the neutron detectors. The study results of the new liquid scintillator with mass concentration of boron up to $6 \%$, based on linear alkylbenzene and contained as a boron additive ortho-carborane, are presented in the paper. The transparency spectra, scintillation characteristics of the new material and the detection efficiency for thermal neutrons have been studied.
\end{abstract}

\begin{abstract}
Высокое сечение захвата тепловых нейтронов ядром ${ }^{10} \mathrm{~B}$ дает возможность использовать борсодержащие органические сцинтилляторы в качестве рабочего вещества нейтронных детекторов. В работе представлены результаты исследования нового жидкого сцинтиллятора с массовой долей бора, достигающей $6 \%$, полученного на основе линейного алкилбензола и содержащего в качестве борсодержащей добавки о-карборан. Измерены и представлены спектры пропускания, сцинтилляционные характеристики нового материала и значения әффективности регистрации тепловых нейтронов.
\end{abstract}

Борвмісний рідкий сиинтилятор. І.Б.Немченок, Н.А.Гундорін, І.І.Камнев, Е.А.Шевчік, А.А.Шуренкова.

Високий перетин захоплення теплових нейтронів ядром ${ }^{10} \mathrm{~B}$ дає можливість використовувати борвмісні органічні сцинтилятори в якості робочої речовини нейтронних детекторів. У даній роботі представлено результати дослідження нового рідкого сцинтилятора 3 масовою часткою бору, що досягає $6 \%$, отриманого на основі лінійного алкілбензолу і що містить як борвмісна добавка о-карборан. Виміряно і представлено спектри пропускання, сцинтиляційні характеристики нового матеріалу і значення ефективності реєстрації теплових нейтронів.

\section{Introduction}

Liquid scintillators (LS), containing natural isotopic mixture of boron with the mass fraction of ${ }^{10} \mathrm{~B} 19.6 \%$ are the most popular among other materials for thermal neutrons detection. Nucleus of this isotope has a high thermal neutron capture crosssection $\left(3.8 \cdot 10^{3}\right.$ barn $)$ and in this reaction the formation of ${ }^{7} \mathrm{Li}$ and ${ }^{4} \mathrm{He}$ nuclei with energy $1.47 \mathrm{MeV}$ and $0.84 \mathrm{MeV}$, respectively take place [1]. The lithium nucleus is formed with a high probability in the excited state and after transition to the ground state emits $\gamma$-quanta with energy of $0.478 \mathrm{MeV}$ :

$$
\begin{aligned}
& n+{ }^{10} \mathrm{~B} \rightarrow{ }^{7} \mathrm{Li}{ }^{*}+\alpha+2.31 M e V \\
&{ }^{7} \mathrm{Li}+\gamma(0.478 \mathrm{MeV}) .
\end{aligned}
$$

Registration of these particles and $\gamma$-quanta evidences of the thermal neutron's capture.

To obtain the boron-loaded liquid scintillators it is necessary to dissolve the boroncontaining additives in main substance of $\mathrm{CH}$-based LS (so called "standard composition", consisting of the main substance of the scintillator and scintillation additives). Trimethylborate is the most common mate- 
rial for these purposes [2-11]. Its widespread usage is due to the availability and good solubility in a lot of organic solvents such as toluene, pseudocumene, phenylcyclohexane, isopropylbiphenyl, 1-methylnaphthalene, 1,6-dimethylnaphthalene. There are commercially available BC-523A [10] and EJ-339A [11] among these LS.

In spite of a sufficient internal diversity, this group of liquid scintillators has common significant disadvantages related to the peculiarities of trimethylborate properties:

- low boron content (17.5\%) in trimethylborate requires the use of high concentrations (up to $50 \%$ ) what negatively affects the light output. BC-523A and EJ-339A are exceptions, because of containing trimethylborate enriched with ${ }^{10} \mathrm{~B}$;

- trimethylborate as other esters of boric acid, is sensitive to moisture that causing hydrolysis and formation of insoluble in organic solvents boric acid. The main reason of instability properties and impossibility of long-time use of the LS is sedimentation of this compound.

In 1965, Ross and Holsopple published an article [12], which describes the properties of liquid scintillator with $\mathrm{N}, \mathrm{N}, \mathrm{N}$ trimethylborazole as a solvent.

$\mathrm{N}, \mathrm{N}, \mathrm{N}$-Trimethylborazole (TMB) is a colorless liquid with an aromatic character [13]. The emission spectrum of 1,4-bis(5phenyloxazol-2-yl) benzene) (POPOP) in this solvent does not differ from the spectrum of emission of POPOP in toluene (Fig. 1). TMB-based LS has a high light output (only $5 \%$ less than the light output of the toluene-based scintillator), and high registration efficiency for thermal neutrons: about $65 \%$ if the scintillator thickness is to be $3 \mathrm{~mm}$.

In our opinion, the low availability of N,N,N-trimethylborazole and, obviously, the low flash point are the significant disadvantages of this scintillator, which limits its use.

Since the aim of the present work is to develop LS for the thermal neutrons registration suitable for use in large-scale experiments, the properties of the new material components must conform to a number of conditions. Thus, boron additive should be transparent over a wide spectral range, and have temporal stability, composing of the resistance to various influences (to heat, atmospheric oxygen, hydrolysis, photo-resistant and radiation stability). In addition, the main material of the scintillator (solvent) should provide a high light output

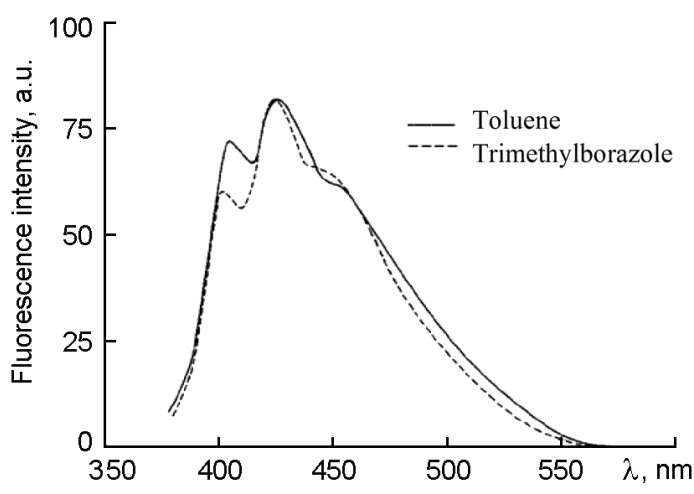

Fig. 1. Fluorescence spectra of POPOP and $\mathrm{N}, \mathrm{N}, \mathrm{N}$-trimethylborazole in toluene [12].

and possess properties such as a high flash point, non-toxicity and availability.

Based on an experience of the plastic scintillators preparation [14], o-carborane was chosen as a boron-containing additive. This polyhedral boron compound, described by the formula $\mathrm{B}_{10} \mathrm{H}_{10} \mathrm{C}_{2} \mathrm{H}_{2}$, is a colorless crystalline substance with high boron content (75 \% wt.), extremely resistant to strong acids, bases and oxidizing agents, it is thermally stable up to $450^{\circ} \mathrm{C}$ [15].

Linear alkylbenzene (LAB) is a large-capacity product of petrochemical industry, widely used for production of biodegradable detergents was used as a scintillator base. Linear alkylbenzene is a tradename of the mixture of few monoalkylated substituted benzene derivatives with a side chain length from 9 to 14 of carbon atoms. Main components of LAB (decylbenzene, undecylbenzene, dodecylbenzene and tridecylbenzene) contain from 10 to 13 carbon atoms in the side chain [16]. Properties of LAB-based "standard composition" scintillator particularly described in one of the preceding articles [17].

2,5-Diphenyloxazole (PPO) was used as a scintillation additive; 1,4-bis(5-phenyloxazol-2-yl) benzene was chosen as a wavelength shifter.

\section{Experimental}

Linear alkylbenzene grade A (LAB) was run through a glass chromatographic column filled with calcined aluminum oxide.

o-Carborane of reagent-grade qualification, 2,5-diphenyloxazole of reagent-grade qualification, 1,4-bis(5-phenyloxazol-2-yl) benzene of reagent-grade qualification and naphthalene of reagent-grade qualification were used without additional purification.

A weighed portion of o-carborane, PPO, POPOP were dissolved in a linear alkylben- 
Table 1. Efficiency of thermal neutrons registration depending on height of the scintillator layer for sample with 6 wt. $\%$ of boron

\begin{tabular}{|c|c|}
\hline $\begin{array}{c}\text { Sample height, } \\
\text { mm }\end{array}$ & $\begin{array}{c}\text { Efficiency of thermal } \\
\text { neutrons registration, \% }\end{array}$ \\
\hline 10 & $30 \pm 3.0$ \\
20 & $38 \pm 3.8$ \\
30 & $40 \pm 4.0$ \\
40 & $45 \pm 4.5$ \\
\hline
\end{tabular}

zene under gentle heating. The concentration of scintillating additives was the same in all cases: 0.5 wt. $\%$ for PPO and 0.0025 wt. $\%$ for POPOP. Transmission spectra of the samples were measured in a quartz cell with a layer $10 \mathrm{~mm}$ thick on a UNICO UV-2804 spectrophotometer relative to air with a scanning step of $1 \mathrm{~nm}$.

Light output was measured as described in [17]. The samples of LS were placed in a teflon cell ( $\varnothing 50 \mathrm{~mm}$ ) with the output ultraviolet glass window. The height of the scintillator layer in the cell was $20 \mathrm{~mm} .{ }^{207} \mathrm{Bi}$ was used as a radioactive source.

The efficiency of thermal neutrons detection was measured as described in [18].

\section{Results and discussion}

In the present paper we obtained and investigated boron-loaded liquid scintillators with boron concentrations of $0.5 \%, 1 \%$, $2 \%, 3 \%, 4 \%, 5 \%, 5.5 \%$ and $6 \%$ of weight. LAB-based "standard composition" LS with the same concentrations of scintillation additives was used as a reference sample to determine an influence of o-carborane additives on the properties of scintillator composition.

As for any other detector, the registration efficiency of radiation is the main property of the scintillator and it is defined as the probability of detection of a particle that entered to the working volume. Light output is specific, but no less important than an efficiency of registration, characteristic of the scintillation material (it implies the number of photons emitted by the scintillator by the absorption of a certain amount of energy).

The values of the thermal neutrons registration efficiency for the new LS samples were measured (Fig. 2). Increase of the boron concentration leads to the significant parameter increment. The sample with mass fraction of boron $6 \%$ is quite five times

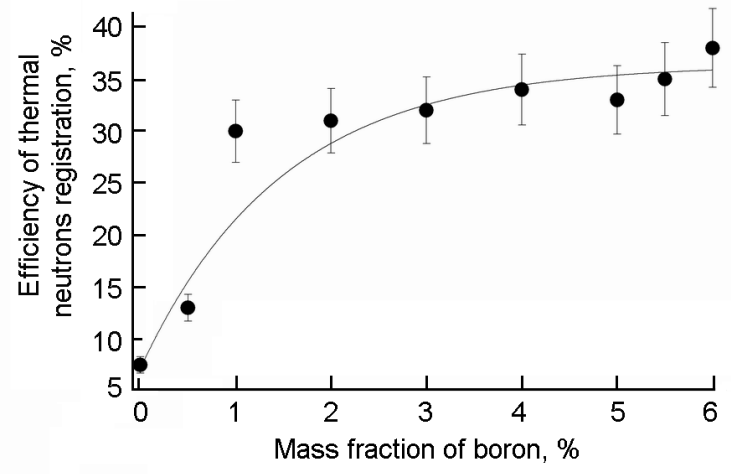

Fig. 2. Dependence of thermal neutrons registration efficiency of liquid scintillators on mass fraction of boron.

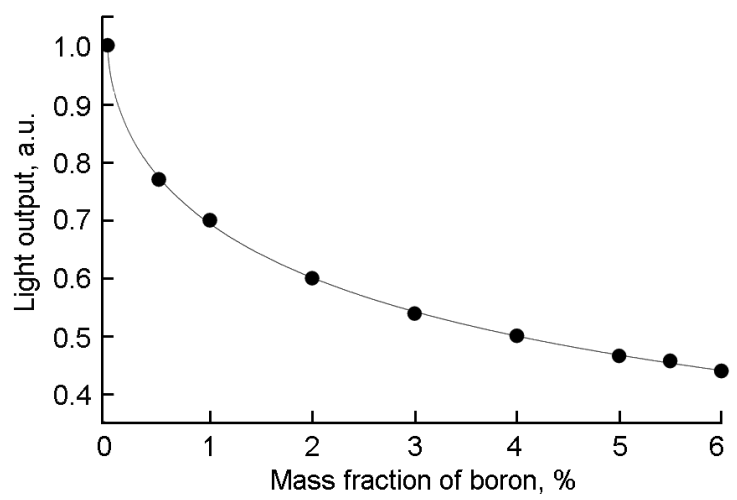

Fig. 3. Dependence of relative light output of liquid scintillators on mass fraction of boron.

greater than the boron-free sample. Heightening of the scintillator layer also causes an increase in the registration efficiency (Table 1). For the LS with mass fraction of boron $6 \%$ the increase in layer thickness from $10 \mathrm{~mm}$ to $40 \mathrm{~mm}$ results in one-and-a-half improvement of the registration efficiency of thermal neutrons. As contrasted to the registration efficiency, light output undergoes a considerable decrease with increasing of boron concentration (Fig. 3).

Such behavior of the concentration dependence of the light output is obviously related to the following factors:

- dilution of the scintillator material with scintillation inactive o-carborane;

- decrease of the LS transparency with increasing of o-carborane concentration (Fig. 4).

The main characteristics of boron-loaded liquid scintillators are summarized in Table 2.

\section{Conclusions}

Boron-loaded liquid scintillators based on linear alkyl benzene with ortho-carborane as 
Table 2. The main characteristics of the new boron-loaded liquid scintillators

\begin{tabular}{|c|c|c|c|c|c|c|c|c|c|}
\hline \multirow[t]{2}{*}{ Parameter } & \multicolumn{9}{|c|}{ Mass fraction of boron, $\%$} \\
\hline & 0 & 0.5 & 1 & 2 & 3 & 4 & 5 & 5.5 & 6 \\
\hline Density, $\mathrm{g} / \mathrm{cm}^{3}$ & 0.865 & 0.871 & 0.877 & 0.888 & 0.902 & 0.914 & 0.927 & 0.934 & 0.940 \\
\hline Light output, a.u.* & 1 & 0.77 & 0.70 & 0.60 & 0.54 & 0.50 & 0.47 & 0.46 & 0.44 \\
\hline $\mathrm{N}(\mathrm{B})$, atoms $/ \mathrm{cm}^{3}, 10^{22}$ & - & 0.02 & 0.04 & 0.07 & 0.11 & 0.15 & 0.19 & 0.21 & 0.23 \\
\hline $\mathrm{N}(\mathrm{C})$, atoms $/ \mathrm{cm}^{3}, 10^{22}$ & 3.81 & 3.82 & 3.83 & 3.85 & 3.88 & 3.89 & 3.92 & 3.93 & 3.94 \\
\hline $\mathrm{N}(\mathrm{H})$, atoms $/ \mathrm{cm}^{3}, 10^{22}$ & 6.32 & 6.35 & 6.38 & 6.44 & 6.52 & 6.59 & 6.66 & 6.69 & 6.73 \\
\hline $\begin{array}{l}\text { Efficiency of thermal } \\
\text { neutrons registration, \% }\end{array}$ & $7.5 \pm 0.8$ & $13 \pm 1.3$ & $30 \pm 3.0$ & $31 \pm 3.1$ & $32 \pm 3.2$ & $34 \pm 3.4$ & $33 \pm 3.3$ & $35 \pm 3.5$ & $38 \pm 3.8$ \\
\hline
\end{tabular}

* Relative to unloaded LAB-based liquid scintillator

boron additive were obtained for the first time. The maximum concentration of boron in the received material is 6 wt. $\%$. The spectral and scintillation properties of the new materials were investigated. New boron-loaded liquid scintillators possess good registration efficiencies of thermal neutrons and due to the physical and chemical properties of linear alkyl benzene could be used in the large-scale experiments.

\section{References}

1. Tables of Physical Quantities, Handbook, ed. by I.K.Kikoin, Atomizdat, Moscow (1976) [in Russian].

2. C.O.Muenlhause, G.E.Thomas, Nucleonics, 1, 44 (1953).

3. L.M.Bollinger, G.E.Thomas, Rev.Sci.Instrum., 28, 489 (1957).

4. G.E.Thomas, Nucl. Instr. Math. Phys. Res., 17, 137 (1962).

5. A.B.Popov, U.S.Yazvitskiy, Pribory $i$ Tekhnika Eksperimenta, 4, 70 (1963).

6. Y.Koike, K.Yamamoto, J.Appl.Phys., 8, 1266 (1969).

7. V.Ya.Kitaev, Pribory $i$ Tekhnika Eksperimenta, 4, 48 (1970).

8. L.R.Greenwood, N.R.Chellew, Rev.Sci.Instrum., 50, 466 (1979).

9. S.C.Wang, C.C.Hsu, R.W.S.Leung et al., Nucl. Instr. Math. Phys. Res., A 432, 111 (1999).

10. www.detectors.saint-gobain.com

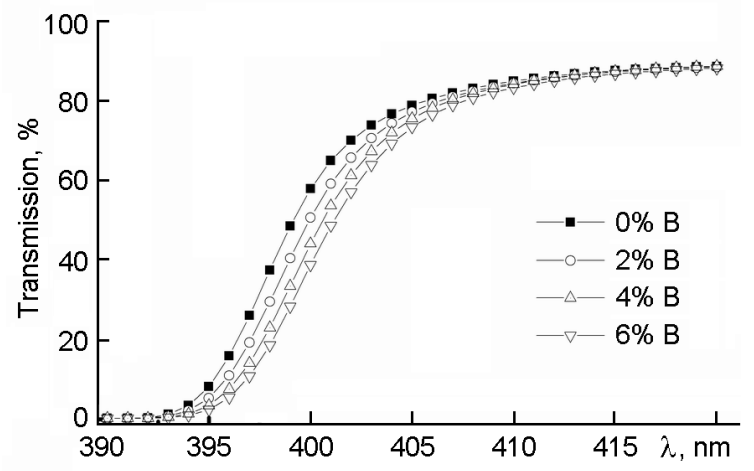

Fig. 4. Transmission spectra of the new boron-loaded scintillators and unloaded one.

11. www.eljentechnology.com

12. H.H.Ross, H.L.Holsopple, Nucl. Instr. Math. Phys. Res., 33, 194 (1965).

13. A.N.Nesmeyanov, R.A.Sokolik, Methods of Organoelement Chemistry, Boron, Aluminum, Gallium, Indium and Thallium, Nauka, Moscow (1964) [in Russian].

14. V.B.Brudanin, O.I.Kochetov, I.B.Nemchenok et al., Izvestiya RAS.Phys. Ser., 65, 60 (2001).

15. R.Grimes, Carboranes. Mir, Moscow (1974) [in Russian].

16. Russian Technical Specifications 2414-02805766480-2006.

17. I.B.Nemchenok, V.I.Babin, V.B.Brudanin et al., Phys. Part. Nucl. Lett., 8, 129 (2011).

18. Y.Ding, N.A.Gundorin, Z.Zhang et al., Functional Materials, 16, 73 (2009). 